\title{
Sebaran suhu, salinitas, kekeruhan dan kecerahan di perairan Laut Tumbak-Bentenan,
} Minahasa Tenggara

(Temperature, salinity, turbidity distribution in Tumbak-Bentenan, Minahasa Tenggara)

\author{
Simon I Patty), Doni Nurdiansah ${ }^{1)}$, Nebuchadnezzar Akbar ${ }^{2}$ \\ ${ }^{1}$ Pusat Penelitian Oseanografi-LIPI \\ ${ }^{2}$ Program Studi Ilmu Kelautan, FPIK. Universitas Khairun. Ternate \\ E-mail:pattysimon@ymail.com
}

Diterima: 12 Mei 2020; Disetujui: 16 Juni 2020

\begin{abstract}
ABSTRAK
Sebaran suhu, salinitas, kekeruhan dan kecerahan di suatu perairan sangat berpengaruh pada berbagai aspek parameter lain, seperti reaksi kimia dan proses biologi. Penelitian mengenai kondisi suhu, salinitas, kekeruhan dan kecerahan air laut di perairan Tumbak-Bentenan, Minahasa Tenggara dilakukan pada bulan Pebruari 2018. Hasilnya menunjukkan suhu air berkisar antara 28,8-30,5 ${ }^{\circ} \mathrm{C}$; salinitas antara 25,0-34,0 \% kecerahan 4,5-31,5 meter. Sebaran nilai suhu, salinitas, kekeruhan dan kecerahan air cukup bervariasi. Bervariasinya suhu, salinitas, kekeruhan dan kecerahan air laut di perairan ini dipengruhi oleh fakktor eksternal antara lain cuaca, angin dan arus. Kondisi suhu, salinitas, kekeruhan dan kecerahan air masih tergolong normal dan baik untuk kehidupan biota laut.
\end{abstract}

Kata kunci : suhu, salinitas, kecerahan, kekeruhan, Tumbak-Bentenan, Minahasa Tenggara.

\begin{abstract}
The distribution of temperature, salinity, turbidity and brightness in a waters greatly affects various aspects of other parameters, such as chemical reactions and biological processes. Research on the conditions of temperature, salinity, turbidity and brightness of sea water in the waters of Tumbak-Bentenan, Southeast Minahasa was conducted in February 2018. The results showed water temperatures ranged from $28.8-30.5{ }^{\circ} \mathrm{C}$; salinity between $25.0-34.0 \%$ or turbidity of 0.21-6.31 NTU and brightness of 4.5-31.5 meters. The distribution of temperature, salinity, turbidity and water brightness varies considerably. The variation of temperature, salinity, turbidity and brightness of sea water in these waters is affected by external factors such as weather, wind and currents. Conditions of temperature, salinity, turbidity and brightness of water are still classified as normal and good for marine life.
\end{abstract}

Keywords: temperature, salinity, brightness, turbidity, Tumbak-Bentenan, Southeast Minahasa 


\section{Pendahuluan}

Perairan Tumbak-Bentenan merupakan perairan pantai dan estuari yang berada di Minahasa Tenggara, Sulawesi Utara. Perairan ini dijadikan nelayan setempat sebagai daerah penangkapan ikan dan budidaya. Hal ini dapat dimengerti karena perairan tersebut kondisinya subur dan merupakan konsentrasi berbagai jenis ikan dan biota laut lainnya dalam jumlah kelimpahan yang besar. Perairan Tumbak-Bentenan tergolong daerah yang produktif dikarenakan memiliki percampuran antara air laut dan air tawar, yang menyebabkan perairan memiliki tingkat kesuburan yang baik (Hutabarat, 2001).

Ditinjau dari letak geografisnya, perairan ini relatif terbuka, berhadapan langsung dengan laut Maluku sehingga mudah terpengaruh oleh massa air dari laut tersebut seperti halnya pola aliran arus, pasang surut yang dinamis, gelombang dan aliran sungai ke laut maupun kegiatan di daratan. Kondisi fisik perairan dipengaruhi oleh banyak faktor, baik yang eksternal maupun internal (Ippen, 1966). Pengaruh eksternal dapat berasal dari laut lepas yang mengelilinginya antara lain arus, pasang surut, gelombang, suhu dan salinitas, maupun dari daratan yang berupa aliran air tawar dari sungai. Sedangkan pengaruh internal antara lain bentuk teluk maupun bentuk topografi dasar perairan. Pada perairan Tumbak-Bentenan seringkali didominasi oleh proses percampuran dan penyebaran air tawar sampai ke laut lepas. Masukan air tawar selain dari curah hujan, juga berasal dari beberapa aliran sungai yang ada di sekitar perairan ini. Hal ini akan menyebabkan terjadinya interaksi antara air tawar dengan air laut sehingga dapat mempengaruhi kondisi oseanografi perairan.

Gambaran oseanografi suatu perairan laut adalah deskripsi dari penyebaran atau distribusi spasial maupun temporal dari parameter suhu, salinitas, kekeruhan dan kecerahan air laut. Pengamatan suhu, salinitas dan kekeruhan merupakan parameter yang tak dapat dipisahkan dalam setiap penelitian di laut. Hal ini karena berbagai aspek distribusi parameter seperti reaksi kimia dan proses biologi merupakan fungsi dari suhu, sehingga suhu ini menjadi suatu variabel yang menentukan. Sedangkan salinitas merupakan faktor penting bagi penyebaran organisme perairan laut dan kekeruhan dapat menghalangi proses fisika dan produktivitas biologi. Kekeruhan menggambarkan kurangnya kecerahan perairan akibat adanya bahan-bahan koloid dan tersuspensi seperti lumpur, bahan organik dan anorganik maupun mikroorganisme perairan (Wilson, 2010). Penelitian tentang sebaran parameter lingkungan di laporkan Patty dan Akbar (2018) di Perairan Terumbu Karang Ternate, Tidore dan sekitarnya dan Patty et al (2019) di teluk Manado. Namun informasi tentang sebaran parameter lingkungan di Perairan TumbakBentenan, Minahasa Tenggara minim informasi. Tulisan ini dimaksudkan untuk mengetahui sebaran suhu, salinitas, kekeruhan dan kecerahan air laut di perairan Tumbak-Bentenan, Minahasa Tenggara. Selanjutnya sebagai informasi awal untuk mengetahui kondisi fisika oseanografi yang terjadi di perairan ini.

\section{Metode penelitian}

\section{II.1. Waktu dan tempat penelitian}

Penelitian dilaksanakan di perairan Tumbak-Bentenan, Minahasa Tenggara dilaksanakan pada bulan Pebruari 2018. Parameter lingkungan yang diukur diantaranya adalah suhu, salinitas, kekeruhan dan kecerahan air laut. Penentuan posisi masing-masing stasiun penelitian dilakukan dengan menggunakan Garmin handportable GPS Map 60 CSx (Gambar 1).

Citasi : Patty S I, Nurdiansah D, Akbar N. 2020. Sebaran suhu, salinitas, kekeruhan dan 


\section{II.2. Pengambilan data perairan}

Sampel air laut diambil dengan menggunakan botol Nansen dari lapisan permukaan pada 16 stasiun pengamatan. Pengukuran suhu, salinitas, kecerahan dilakukan secara in situ (langsung di lapangan). Suhu air laut diukur dengan menggunakan thermometer GMK-910T, salinitas diamati dengan menggunakan Atago hand refractometer dan kecerahan air laut diukur dengan cakram sechi (sechi disk). Sedangkan kekeruhan air laut dilakukan secara ex situ (di labaratorium WLN-Manado), dengan menggunakan metode turbidimetri. Semua metode analisis berdasarkan pada buku Standards Methods for The Examination of Water and Wastewater (APHA, AWWA, WEF, 2005). Data diolah dan disajikan dalam bentuk peta sebaran dengan perangkat lunak, SURFER dan ArcGis.

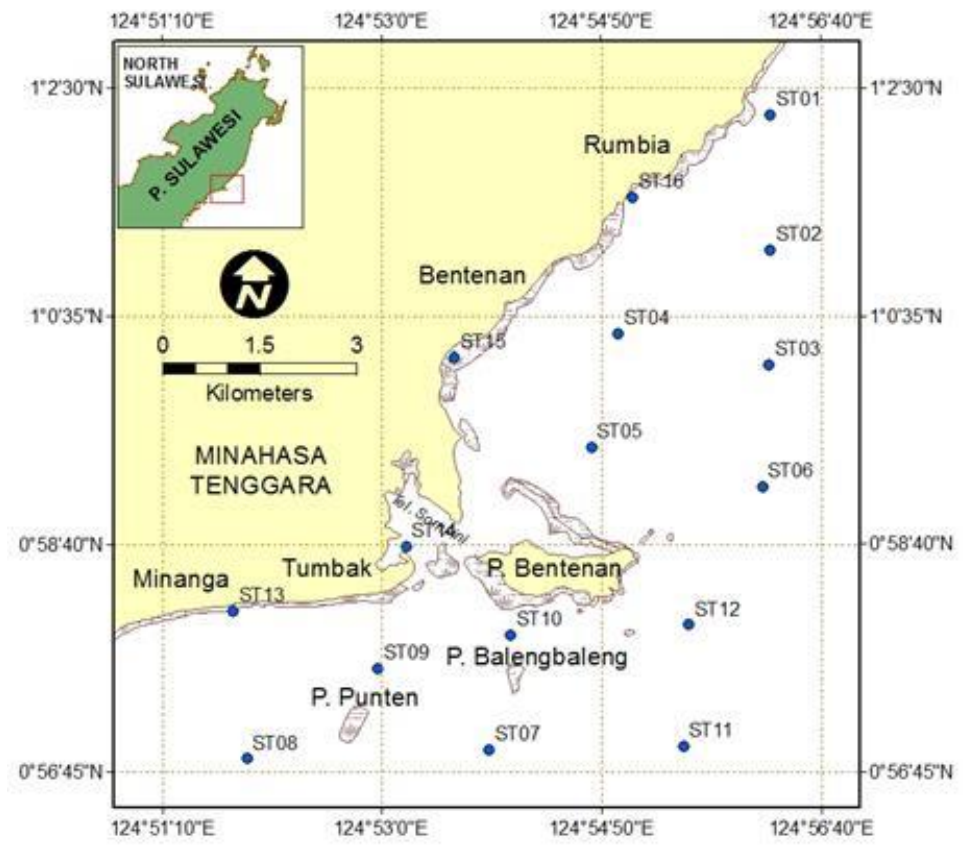

Gambar 1. Stasiun penelitian

\section{Hasil dan pembahasan}

\section{III.1. Suhu}

Perubahan suhu sangat berpengaruh terhadap proses fisika, kimia, maupun biologi perairan (Effendi, 2003). Suhu air yang diperoleh di perairan Tumbak-Bentenan sedikit bervariasi dengan nilai koefisien vasiasinya $1,63 \%$. Bervariasinya nilai suhu air yang terjadi, mengindikasikan bahwa nilai suhu di perairan ini dipengruhi oleh fakktor eksternal antara lain cuaca dan angin. Angin yang berhembus kencang di atas permukaan laut akan menyebabkan penguapan dan mengalirkan panas dari laut ke udara. Penguapan dan pemindahan panas itu menyebabkan laut kehilangan energi dan mengakibatkan pendinginan. Sebaliknya melemahnya angin yang berhembus di atas permukaan laut berarti lapisan permukaan semakin tenang, sehingga penyinaran matahari sangat efektif bagi pemanasan massa air pada lapisan permukaan secara langsung yang mengakibatkan suhu air permukaan menjadi naik. Officer, 1976 
mengemukakan bahwa kondisi suhu air di suatu perairan di pengaruhi terutama oleh kondisi atmosfir, cuaca dan intensitas matahari yang masuk ke laut.

Tabel 1. Hasil statistik deskriptif suhu, salinitas, kekeruhan dan kecerahan air laut di perairan Tumbak-Bentenan.

\begin{tabular}{|c|c|c|c|c|c|c|}
\hline St. & Latitude & Longitude & $\begin{array}{l}\text { Suhu } \\
\left({ }^{\circ} \mathrm{C}\right)\end{array}$ & $\begin{array}{c}\text { Salinitas } \\
(\%)\end{array}$ & $\begin{array}{c}\text { Turbiditas } \\
\text { (NTU) }\end{array}$ & $\begin{array}{c}\text { Kecerahan } \\
\text { (meter) }\end{array}$ \\
\hline 1 & 1.03776 & 124.93728 & 29.9 & 33.5 & 0.42 & 19.5 \\
\hline 2 & 1.01887 & 124.93734 & 29.8 & 33.5 & 0.26 & 21.5 \\
\hline 3 & 1.00276 & 124.93715 & 30.0 & 34.0 & 0.76 & 24.0 \\
\hline 4 & 1.00714 & 124.91620 & 30.2 & 33.0 & 0.37 & 15.5 \\
\hline 5 & 0.99127 & 124.91243 & 30.1 & 33.0 & 0.27 & 18.0 \\
\hline 6 & 0.98575 & 124.93621 & 29.8 & 34.0 & 0.28 & 29.0 \\
\hline 7 & 0.94892 & 124.89817 & 30.1 & 33.0 & 0.21 & 28.0 \\
\hline 8 & 0.94766 & 124.86453 & 30.4 & 32.0 & 0.35 & 28.0 \\
\hline 9 & 0.96032 & 124.88275 & 30.3 & 32.0 & 0.32 & 27.5 \\
\hline 10 & 0.96494 & 124.90117 & 30.3 & 33.0 & 0.31 & 25.0 \\
\hline 11 & 0.94936 & 124.92531 & 28.9 & 33.0 & 0.37 & 15.5 \\
\hline 12 & 0.96639 & 124.92601 & 28.8 & 33.5 & 0.27 & 31.5 \\
\hline 13 & 0.96841 & 124.86266 & 30.5 & 25.0 & 6.31 & 8.0 \\
\hline 14 & 0.97736 & 124.88667 & 30.0 & 31.5 & 0.51 & 4.5 \\
\hline 15 & 1.00387 & 124.89347 & 30.3 & 30.0 & 5.18 & 4.5 \\
\hline 16 & 1.02626 & 124.91817 & 30.3 & 29.0 & 0.92 & 4.5 \\
\hline \multicolumn{3}{|c|}{ Minimum } & 28.8 & 25.0 & 0.21 & 4.5 \\
\hline \multicolumn{3}{|c|}{ Maksimum } & 30.5 & 34.0 & 6.31 & 31.5 \\
\hline \multicolumn{3}{|c|}{ Rerata } & 30.0 & 32.1 & 1.07 & 19.0 \\
\hline \multicolumn{3}{|c|}{ Standart deviasi } & 0.49 & 2.34 & 1.85 & 9.43 \\
\hline \multicolumn{3}{|c|}{ Koefisien variasi } & 1.63 & 7.29 & $>100$ & 49.58 \\
\hline \multicolumn{3}{|c|}{ Baku mutu* } & $28-30$ & $33-34$ & $<5$ & $>5$ \\
\hline
\end{tabular}

* Baku mutu air laut untuk biota laut (Kepmen LH No 51 Tahun 2004) 


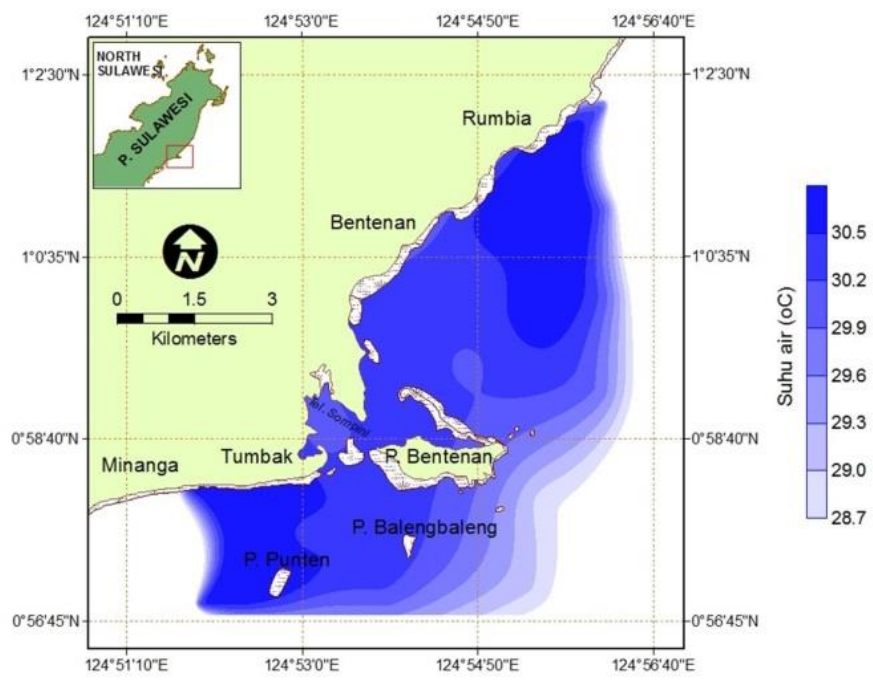

Gambar 2. Sebaran suhu perairan Tumbak-Bentenan.

Suhu air di perairan perairan Tumbak-Bentenan berkisar antara $28,8-30,5{ }^{\circ} \mathrm{C}$, dengan nilai rata-rata $30,0 \pm 0,49{ }^{\circ} \mathrm{C}$. Suhu ini masih dalam kisaran suhu air di perairan laut umumnya, dimana nilai suhu di lapisan permukaan laut yang normal berkisar antara $20,0-30,0{ }^{\circ} \mathrm{C}$ (Nybakken, 1988). Manurut Nontji, 2002 bahwa suhu air laut permukaan di perairan Indonesia pada umumnya, yaitu berkisar antara 28-31 ${ }^{\circ} \mathrm{C}$. Nilai suhu air yang diperoleh tidak berbeda dengan beberapa perairan di Sulawesi Utara yang pernah diamati, diantaranya di Selat Lembeh (Mei-Juli, 2008) berkisar antara 28,4 - 30,1 ${ }^{\circ} \mathrm{C}$ (Yusron, 2008); perairan Teluk Manado (MeiOktober, 2006) berkisar antara 29,0 -31,0 ${ }^{\circ} \mathrm{C}$ (Ijong, 2011) dan (September 2010) berkisar antara 28,0-29,7 ${ }^{\circ} \mathrm{C}$ (Kalangi dkk., 2013). Keadaan suhu di perairan ini masih masih baik untuk kehidupan biota laut yaitu $28-32{ }^{\circ} \mathrm{C}$ dan diperbolehkan terjadi perubahan sampai dengan $<2{ }^{\circ} \mathrm{C}$ dari suhu alami (Kepmen LH No 51 Tahun 2004).

Sebaran suhu air laut menunjukkan nilai $>29,6{ }^{\circ} \mathrm{C}$ mendominasi perairan dan penyebarannya menuju ke arah darat, sebaliknya ke arah laut lepas suhu airnya makin rendah. Fluktuasi suhu air cukup kecil mencapai $0,3{ }^{\circ} \mathrm{C}$, sehingga dapat dikatakan bahwa distribusi suhu adalah homogen (Gambar 2). Dari Gambar 2, terlihat bahwa suhu air di perairan dekat pantai relatif lebih tinggi daripada di lepas pantai. Kondisi ini disebabkan karena pergerakan massa air tawar dari aliran sungai-sungai yang dengan mudah masuk ke perairan dekat pantai. Gerakan massa air ini yang dapat menimbulkan panas, akibat terjadi gesekan antara molekul air, sehingga suhu air laut di perairan dekat pantai lebih hangat dibanding dengan massa air di perairan lepas pantai (Tarigan dan Edward, 2000).

\section{III.2. Salinitas}

Salinitas air laut di perairan ini bervariasi dengan nilai koefisien variasinya mencapai 7,29\%. Banjarnahor, 2000 mengatakan bahwa perbedaan nilai salinitas air laut dapat disebabkan oleh terjadinya pengacauan (mixing) akibat gelombang laut ataupun gerakan massa air yang ditimbulkan oleh tiupan angin. Hasil pengamatan menunjukkan bahwa salinitas di perairan Tumbak-Bentenan berkisar antara $25,0-34,0 \%$, dengan nilai rata-rata $32,1 \pm 2,34 \%$. Salinitas permukaan perairan ini relatif lebih rendah bila dibandingkan dengan salinitas permukaan 
perairan Sulawesi dan sekitarnya. Hadikusumah dan Sugiarto (2001) mengungkapkan bahwa salinitas permukaan sampai pada kedalaman 10 meter perairan Sulawesi dan sekitarnya berkisar berkisar antara 33,7-33,8 \% . Rendahnya nilai salinitas di perairan ini menunjukkan adanya pengaruh dari daratan seperti percampuran dengan air tawar yang terbawa aliran sungai. Menurut Nontji (2002) bahwa tinggi rendahnya nilai salinitas di laut dipengaruhi oleh berbagai faktor, seperti pola sirkulasi air, penguapan (evaporasi), curah hujan (presipitasi) dan adanya aliran sungai.

Sebaran salinitas menunjukkan nilai $<31,0 \%$ penyebarannya menuju ke arah darat sebaliknya ke arah laut nilai salinitasnya makin tinggi, dengan fluktuasi salinitas mencapai 1,5 $\%$ (Gambar 2). Dilihat dari sebaran, maka salinitas sekitar pantai lebih rendah dari pada salinitas laut lepas. Hal ini disebabkan karena air laut yang berada dekat daratan masih memiliki pengaruh dari air sungai hingga menyebabkan salinitas di daerah ini kecil. Sebaliknya, salinitas di perairan laut lepas sudah tidak memiliki pengaruh dari darat, sehingga salinitasnya pun besar (Nybakken, 1988). Bowden dalam Nurhayati (2002) mengemukakan bahwa keberadaan nilai salinitas dalam distribusinya di perairan laut sangat dipengaruhi oleh beberapa faktor antara lain adanya interaksi masuknya air tawar ke dalam perairan laut melalui sungai, juga dipengaruhi penguapan dan curah hujan

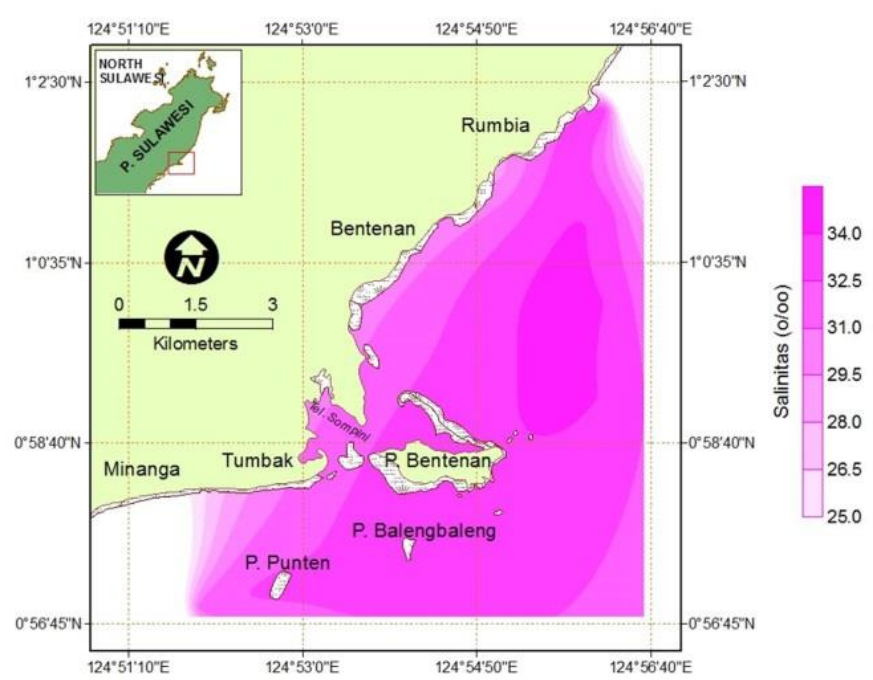

Gambar 3. Sebaran salinitas perairan Tumbak-Bentenan.

Pada umumnya nilai salinitas wilayah laut Indonesia berkisar antara $28-33 \%$ (Nontji, 2002). Nilai salinitas di perairan Tumbak-Bentenan tidak berbeda bila dibandingkan dengan perairan Teluk Amurang berkisar antara $25-34 \%$ dengan rata-rata 31,0 $\pm 2,37 \%$ oo (Patty, 2018). Dari hasil pengukuran salinitas terlihat nilainya masih $<32,0 \%$, maka perairan masih dipengaruhi oleh pantai, diduga adanya pengaruh dari daratan seperti percampuran dengan air tawar yang terbawa aliran sungai. Salinitas ini masih berada dalam batas-batas salinitas yang normal air pantai dan air campuran. Di daerah pesisir (air pantai dan air campuran) salinitas berkisar antara 32,0-34,0\% dan di laut terbuka umumnya salinitas berkisar antara 33-37\% dengan rata-rata $35 \%$ (K. Romimohtarto dan S. S. Thayib, 1982). Kepmen LH No 51 Tahun

Citasi : Patty S I, Nurdiansah D, Akbar N. 2020. Sebaran suhu, salinitas, kekeruhan dan 
2004 menetapkan salinitas sebesar 33-34 \%o salinitas alami untuk terumbu karang dan diperbolehkan terjadi perubahan sampai dengan $<5 \%$ salinitas rata-rata musiman.

\section{III.3. Kekeruhan}

Nilai kekeruhan air laut di perairan Tumbak-Bentenan berkisar antara 0,21-6,31 NTU dengan nilai rata-rata 1,07 $\pm 1,85$ NTU. Nilai koefisien vasiasinya $>100 \%$ menunjukkan nilai kekeruhan antar stasiun sangat bervariasi. Dari hasil pengukuran kekeruhan terlihat dua stasiun nilainya sangat tinggi > 5 NTU yaitu stasiun 13 dan stasiun 15, berbeda dengan stasiun-stasiun lainnya < 1 NTU. Tingginya kekeruhan air di stasiun 13 dan stasiun 15 diduga disebabkan air lapisan permukaan banyak mengandung materi tersuspensi seperti lumpur, bahan organik dan anorganik maupun mikroorganisme perairan, karena kedua stasiun dekat dengan sungai. Kekeruhan biasanya dicirikan oleh konsentrasi tinggi materi tersuspensi, kondisi ini umum terjadi pada perairan estuari yang mengindikasikan besarnya pergerakan sedimen (Brahmana, 1991). Turbulensi dari gelombang maupun arus yang kuat menyebabkan teraduknya substrat hingga air laut keruh.

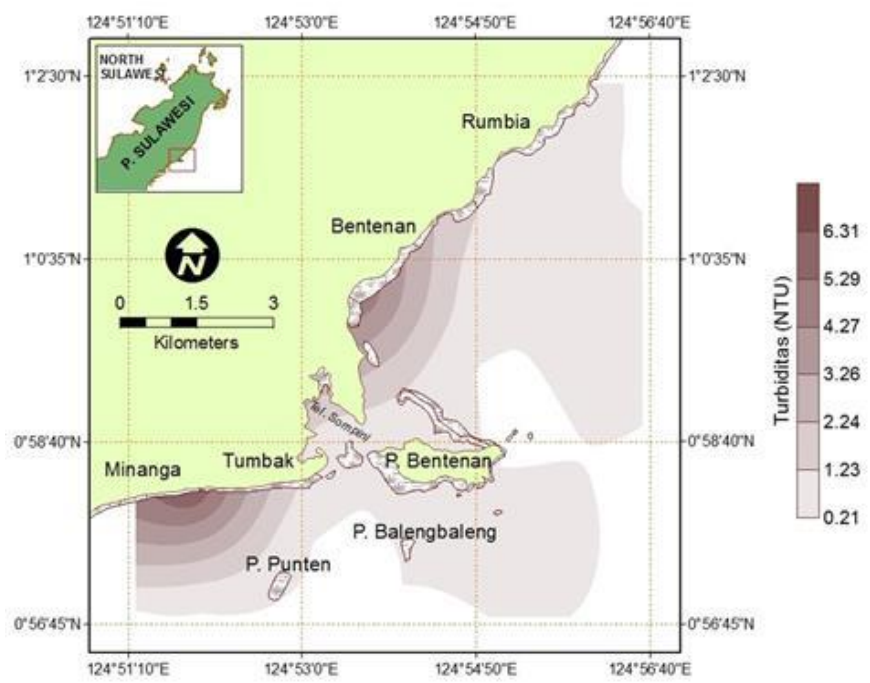

Gambar 4. Sebaran kekeruhan perairan Tumbak-Bentenan.

Kekeruhan air laut dengan nilai tertinggi > 4,27 NTU penyebarannya menuju ke arah darat dekat muara sungai, sebaliknya ke arah laut kekeruhan airnya makin rendah, dengan fluktuasi kekeruhan air laut mencapai 1,02 NTU (Gambar 4). Hal ini menunjukkan bahwa tingkat kekeruhan tertinggi berada di daerah dekat pantai yang cenderung mendapatkan masukan dari daratan. Kecenderungan tingginya kekeruhan air laut di perairan ini ada kaitannya dengan tingkat kebersihan perairan terutama pada saat hujan, namun tidak melebihi baku mutu air laut untuk biota laut yaitu <5 NTU (Kepmen LH No 51 Tahun 2004).

\section{III.4. Kecerahan}

Kecerahan merupakan daya penetrasi cahaya untuk menembus kedalaman laut, apabila perairan keruh maka penetrasi cahaya matahari berkurang sehingga mengakibatkan kecerahan air

Citasi : Patty S I, Nurdiansah D, Akbar N. 2020. Sebaran suhu, salinitas, kekeruhan dan 84 kecerahan di perairan Laut Tumbak-Bentenan, Minahasa Tenggara. Jurnal IImu Kelautan Kepualauan, 3 (1) : 77-87 
rendah. Hasil pengukuran kecerahan air laut pada perairan Tumbak-Bentenan menunjukkan nilai

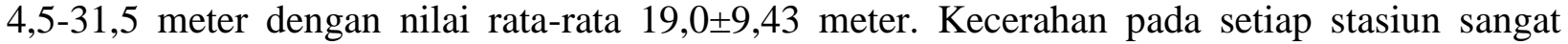
bervariasi dengan nilai koefisien vasiasinya mencapai 49,58\%. Kecerahan terendah $<5$ meter dijumpai pada stasiun-stasiun dekat sungai yang banyak mengandung materi tersuspensi. Menurut Mechta, 1989 bahwa kecerahan sangat tergantung oleh intensitas penyinaran matahari, proses absorbsi dan kandungan materi suspensi. Nilai kecerahan air perairan ini masih di atas baku mutu air yaitu > 5 meter (Kepmen LH No 51 Tahun 2004)

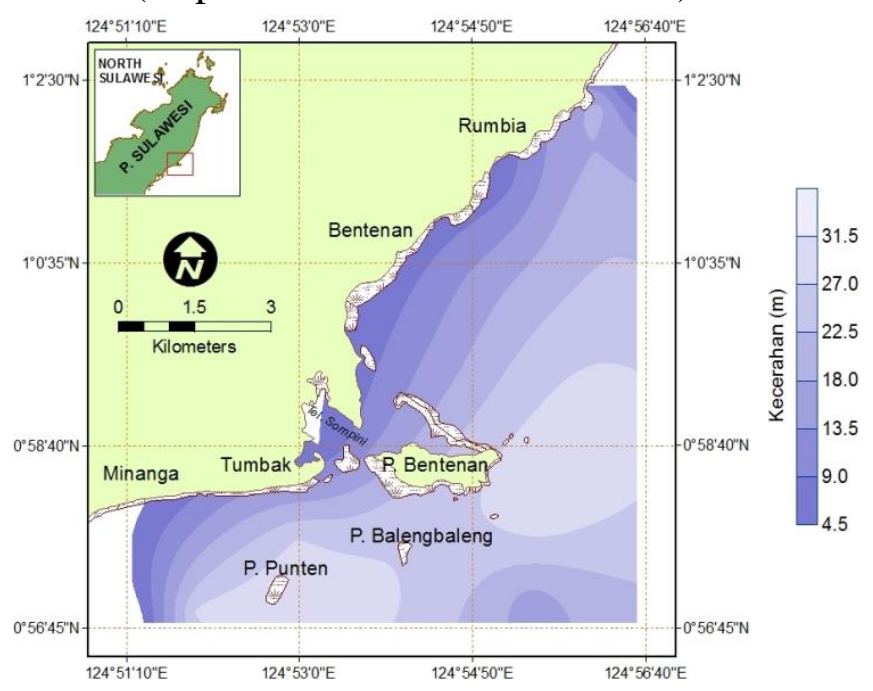

Gambar 5. Sebaran kecerahan perairan Tumbak-Bentenan.

Sebaran kecerahan air menunjukkan nilai > 13,5 meter penyebarannya menuju ke arah laut sebaliknya ke arah darat nilai kecerhannya makin rendah (Gambar 3). Hal ini menunjukkan bahwa di daerah dekat pantai airnya keruh akibat hujan dan resuspensi sedimen oleh arus dan gelombang. Kecerahan air di perairan ini sangat tergantung pada sedimentasi yang berasal dari sungai masuk ke perairan laut. Menurut Effendi, 2003 bahwa kecerahan sangat dipengaruhi oleh cuaca, waktu pengukuran, kekeruhan dan padatan tersuspensi.

\section{Kesimpulan}

Sebaran suhu air laut menunjukkan nilai tertinngi menuju ke arah darat, sebaliknya untuk salinitas nilainya makin rendah karena masih memiliki pengaruh dari air sungai, demikian pula kekeruhan air laut tinggi maka nilai kecerahan rendah dan penyebarannya menuju ke arah darat. Variasi nilai suhu, salinitas, kekeruhan dan kecerahan air laut di perairan Tumbak-Bentenan dipengruhi cuaca, angin dan arus maupun masukan bahan organik dan anorganik dari darat melalui aliran sungai. Nilai suhu, salinitas, kekeruhan dan kecerahan masih dalam kondisi relatif normal untuk kategori perairan pantai.

\section{Daftar Pustaka}

APHA, AWWA, WEF, 2005. Standard Method For The Examination of Water And Wastewater, Edition 21: 4-153.

Citasi : Patty S I, Nurdiansah D, Akbar N. 2020. Sebaran suhu, salinitas, kekeruhan dan 85 kecerahan di perairan Laut Tumbak-Bentenan, Minahasa Tenggara. Jurnal IImu Kelautan Kepualauan, 3 (1) : 77-87 
Brahmana, S.S. 1991. Kualitas air dan sedimen lagoon Segara Anakan. Journal Laporan Penelitian. Th. 6. K.W.111(20). Departemen Pekerjaan Umum: 28-35.

Banjarnahor, J., 2000. Atlas Ekosistem Pesisir Tanah Grogot, Kalimantan Timur. Puslitbang Oseanologi - LIPI Jakarta,hal. 17.

Effendi, H. 2003. Telaah Kualitas Air bagi Pengelolaan Sumber Daya dan Lingkungan Perairan. Kanisius. Yogyakarta.

Hadikusumah dan Sugiarto 2001. Penelitian Sumberdaya Laut di Kawasan Pengelola dan Pengembangan Laut (KAPPEL) Sulawesi Utara. Bidang Oseanografi, Proyek Pengembangan dan Penerapan IPTEK Kelautan. Laporan Akhir. Pusat Penelitian dan Pengembangan Oseanologi. Lembaga llmu Pengetahuan Indonesia: 1-21.

Hutabarat,S. 2001. Pengaruh kondisi oseanografi terhadap perubahan iklim. Produktivitas dan Distribusi Biota Laut. Pidato Pengukuhan Jabatan Guru Besar Madya dalam Ilmu Oseanografi.Fakultas Perikanan dan Ilmu Kelautan. Universitas Diponegoro. Semarang. p. $23-29$.

Ijong, F.G. 2011. Laju Reduksi Merkuri Oleh Pseudomonas Diisolasi Dari Perairan Pantai Teluk Manado. Jurnal Perikanan dan Kelautan Tropis Vol. VII-2, Agustus 2011: 68-69.

Ippen, A.T. 1966. Estuary and Coastline Hydrodynamics. Mc. Graw-Hill Book Company, Inc.: $744 \mathrm{pp}$.

Kalangi, P.N.I., A. Mandagi, K.W.A. Masengi, A. Luasunaung, F.P.T. Pangalila dan M. Iwata. 2013. Sebaran Suhu dan Salinitas di Teluk Manado. Jurnal Perikanan dan Kelautan Tropis, 9 (2):71-75.

Mechta, J., 1989. On estuarine cohesive sediment susvension behavior. Jour. of Geophysical Research. Vol. 94.C10:303-314.

Menteri Negara KLH, 2004. Keputusan Menteri Negara Lingkungan Hidup No.51 Tahun 2004 Tentang Baku Mutu Air Laut Untuk Biota Laut. Jakarta, hal. 32.

Nontji, A. 2002. Laut Nusantara. Penerbit Djambatan. Jakarta: 59-67.

Nurhayati. 2002. Karakteristik Hidrografi dan Arus di Perairan Selat Malaka. Perairan Indonesia Oseanografi, Biologi dan Lingkungan. Puslit Oseanografi LIPI. Jakarta: 1 - 8.

Nybakken, W.J. 1988. Biologi Laut. Suatu Pendekatan Ekologis. Gramedia, Jakarta: 459 hal.

Officer, C.B. 1976. Physical Oseanography of Estuaries and Associated Coastal Waters.John Willey and Sons. New York: 465 pp.

Patty, S.I. 2018. Studi Variasi Suhu, Salinitas dan Oksigen Terlarut pada Musim Barat dan Musim Peralihan-I di Perairan Teluk Amurang, Sulawesi Utara. Prosiding Seminar Pengelolaan Berkelanjutan Sumberdaya Pesisir dan Laut Sulawesi Utara: Arah dan Tantangan. LKBL Bitung, P2O- LIPI : 101-109.

Patty, S.I. dan Akbar N. 2018. Kondisi Suhu, Salinitas, pH dan Oksigen Terlarut di Perairan Terumbu Karang Ternate, Tidore dan Sekitarnya. Jurnal Ilmu Kelautan Kepulauan, 1 (2) ; 1-10.

Patty S.I., Rizki, M.P., Rifai, H dan Akbar, N. .2019.Kajian Kualitas Air dan Indeks Pencemaran Perairan Laut di Teluk Manado Ditinjau Dari Parameter Fisika-Kimia Air Laut. Jurnal Ilmu Kelautan Kepulauan, 2 (2) ; 1-13.

Romimohtarto, K dan Thayib, S.S. 1982. Kondisi Lingkungan dan Laut di Indonesia, LON-LIPI, Jakarta: 246 hal.

Citasi : Patty S I, Nurdiansah D, Akbar N. 2020. Sebaran suhu, salinitas, kekeruhan dan 86 kecerahan di perairan Laut Tumbak-Bentenan, Minahasa Tenggara. Jurnal IImu Kelautan Kepualauan, 3 (1) : 77-87 
Tarigan, M.S. dan Edward. 2000. Perubahan Musiman Suhu, Salinitas, Oksigen Terlarut, Fosfat dan Nitrat di Perairan Teluk Ambon. Pesisir dan Pantai Indonesia IV. Puslitbang Oseanologi-LIPI, Jakarta: hal. 77.

IWilson, P.C. 2010. Water Quality Notes: Water Clarity (Turbidity, Suspended Solids, and Color). Department of Soil and Water Science. University of Florida.

Yusron, E., 2008. Penelitian Biodiversitas Biota Laut di Perairan Selat Lembeh, Laporan Tahunan. UPT. Loka Konservasi Biota Laut-LIPI Bitung, hal. 86. 